\title{
Adsorptive Removal of Phosphate from Aqueous Solution by Magnetic-Supported Kaolinite: Characteristics, Isotherm and Kinetic Studies
}

\section{Adebola Abosede Adeyi1, Toluwalope Gbemileke Abayomi ${ }^{1,2 *}$, Mihir Kumar Purkait ${ }^{3}$, Piyal Mondal $^{3}$}

${ }^{1}$ Departmenet of Chemistry, University of Ibadan, Ibadan, Nigeria

${ }^{2}$ Department of Chemical Science, Adekunle Ajasin University, Akungba Akoko, Nigeria

${ }^{3}$ Department of Chemical Engineering, Indian Institute of Technology Guwahati, Guwahati, India

Email: *toluwalopeabayomi1201@gmail.com

How to cite this paper: Adeyi, A.A., Abayomi, T.G., Purkait, M.K. and Mondal, P. (2019) Adsorptive Removal of Phosphate from Aqueous Solution by Magnetic-Supported Kaolinite: Characteristics, Isotherm and Kinetic Studies. Open Journal of Applied Sciences, 9, 544-563.

https://doi.org/10.4236/ojapps.2019.97043

Received: May 27, 2019

Accepted: July 15, 2019

Published: July 18, 2019

Copyright $\odot 2019$ by author(s) and Scientific Research Publishing Inc. This work is licensed under the Creative Commons Attribution International License (CC BY 4.0).

http://creativecommons.org/licenses/by/4.0/

c) (i) Open Access

\begin{abstract}
Natural kaolin (NK) and magnetite-modified kaolin (MK) prepared by co-precipitation were used as adsorbents to remove phosphate from aqueous solution. The materials were characterized using X-ray diffractometer (XRD), Fourier transform infrared spectroscopy (FTIR), field-emission scanning electron microscope (FESEM), and vibrating sample magnetometer (VSM). Batch adsorption experiment was carried out to determine the phosphate removal efficiencies of these materials. The magnetic-supported kaolin showed better dispersion and less co-aggregation which ensured better fusion of the kaolin with magnetite $\left(\mathrm{Fe}_{3} \mathrm{O}_{4}\right)$. The removal process of phosphate was governed by physico-chemical process. The results demonstrated that the adsorption of phosphate onto $\mathrm{NK}$ and $\mathrm{MK}$ was highly $\mathrm{pH}$-dependent and the kinetics of the adsorption followed pseudo-second order equation. The adsorption data of Mk adsorbent fitted better with the Freundlich isotherm equation. The MK showed much better adsorption capacity per mass of MK $(52.91 \mathrm{mg} / \mathrm{g})$ than untreated NK (17.61 mg/g). Since the magnetic kaolin can be easily prepared, it enables promising application for the removal of phosphate from aqueous solution. Hence, this new class of efficient adsorbent (MK), can have a variety of application in industrial processes.
\end{abstract}

\section{Keywords}

Magnetite, Kaolin, Phosphate, Adsorption 


\section{Introduction}

Water pollution, caused by organic and inorganic compounds from natural and anthropogenic sources, produced a very large amount of polluted water that are indiscriminately discharged into the environment. Phosphate, an essential element, which supports the growth of most biological organisms in aquatic environment has otherwise proven to be dangerous in the environment if the concentration exceeds certain limits [1] [2]. This inorganic pollutant severely induced eutrophication, which deteriorates water quality and depopulates aquatic biota [3]. Consequently, several approaches have been developed to remove excessive phosphate from our environment. The investigated approaches include adsorption, reverse osmosis, ion-exchange, ultrafiltration, nano-filtration, precipitation, solvent extraction or electrolytic process [4] [5] [6] [7] [8].

The adsorption process is amongst the preferred method because it is economical, versatile and simple [9]. Adsorption has the overall advantage of applicability at very low concentrations, suitability for using batch and continuous processes, ease of operation, little sludge generation, possibility of regeneration and reuse of adsorbent [10]. However, a number of other techniques have proven either highly cost ineffective or, effectively deficient at high and/or low contaminant concentrations.

Clay is among several low-cost adsorbents used to treat wastewater [11]. Clay generally such as montmorillonite [11], kaolin [12] and sepiolite [13] has been reported with high specific surface area and as an effective adsorbent. In addition, modified forms of clay have in recent times gained researchers and industrialist's attention. The choice of magnetic-modified clay (kaolin) in this study is informed by its high adsorption capacity plus, superb magnetic advantage in eventual separation process [13]. Magnetic technology has brought great innovation to separation technology. It has been reported to improve the efficiencies of other types of separation techniques, such as catalytic and membrane processes [14] [15] [16]. Besides the unique magnetic properties of magnetite $\left(\mathrm{Fe}_{3} \mathrm{O}_{4}\right)$, it has also been reported to possess larger surface area, which is an advantage in adsorption process. Recently, the combination of $\mathrm{Fe}_{3} \mathrm{O}_{4}$ and kaolin has been developed to enhance the separation of kaolin in aqueous solution [17]. In this study, the co-precipitation method was used for the synthesis of the clay-magnetite composite. A combination of iron (II) and (III) salts of chloride were used. Over the time past, limited information is available on the differences in strength of magnetite $\left(\mathrm{Fe}_{3} \mathrm{O}_{4}\right)$ : owing to varying types of precursor salts and iron ratio used in its preparation. Hence, a considerable attention would therefore be given to available materials in magnetite preparations and, the ratio of combination of available iron salts. This no doubt, would yield optimal use of this new class of magnetic-clay adsorbent. This therefore would be applied in the removal of phosphate from aqueous solution. This magnetic composite can be easily separated from solution by external magnet after adsorption process. This innovative composite is hereby proposed for the phosphate recovery from wastewater using 
magnetic assistance [18].

The aim of this study was to explore the feasibility of using magnetic-kaolinite composite for phosphate adsorption from aqueous solution. The phosphate adsorption equilibrium, kinetics as well as the influences of other factors (i.e. $\mathrm{pH}$, solid/liquid ratio) on the phosphate removal were studied.

\section{Materials and Methods}

\subsection{Materials}

Natural kaolin samples were collected from different clay deposits in the south-western region of Nigeria [19]. Other chemical reagents used include, potassium dihydrogen phosphate $\left(\mathrm{KH}_{2} \mathrm{PO}_{4}\right)$, ferric chloride hexahydrate $\left(\mathrm{FeCl}_{3} \cdot 6 \mathrm{H}_{2} \mathrm{O}\right)$, ferrous chloride tetra-hydrate $\left(\mathrm{FeCl}_{2} \cdot 4 \mathrm{H}_{2} \mathrm{O}\right)$, iron (II) and (III) sulfate $\left(\mathrm{FeSO}_{4}\right)$ and $\left(\mathrm{Fe}_{2}\left(\mathrm{SO}_{4}\right)_{3}\right.$, sodium hydroxide $(\mathrm{NaOH})$, hydrogen chloride $(\mathrm{HCl})$, hydrogen peroxide $\left(\mathrm{H}_{2} \mathrm{O}_{2}\right)$, sulfuric acid $\left(\mathrm{H}_{2} \mathrm{SO}_{4}\right)$, potassium antimonyl tartrate $\mathrm{K}(\mathrm{SbO}) \mathrm{C}_{4} \mathrm{H}_{4} \mathrm{O}_{6} \cdot 1 / 2 \mathrm{H}_{2} \mathrm{O}$, ammonium molybdate $\left.\left(\mathrm{NH}_{4}\right)_{6} \quad \mathrm{Mo}_{7} \mathrm{O}_{24} \cdot 4 \mathrm{H}_{2} \mathrm{O}\right)$ and ascorbic acid. All the chemicals were analytical grade and purchased from AB-Chemicals and Co. India. The chemicals were used without any further purification.

\subsection{Methods}

\section{Preparation of Adsorbent}

Natural kaolin was collected from the source, hydrogen peroxide was bubbled through it to get rid of any organic impurities, washed, sun-dried, mechanically crushed and sieved to 180 mesh [20]. Subsequently, the sample was oven-dried at $105^{\circ} \mathrm{C}$ overnight to obtain the natural kaolin (NK). This was stored for further application.

The kaolin-supported magnetite was prepared with NK by Co-precipitation method. This method involves the following steps: the salts of $\mathrm{FeCl}_{2} \cdot 4 \mathrm{H}_{2} \mathrm{O}$ and $\mathrm{FeCl}_{3} \cdot 6 \mathrm{H}_{2} \mathrm{O}$ with molar ratio of $\mathrm{Fe}(\mathrm{II}) / \mathrm{Fe}(\mathrm{III})=1 / 2$ were dissolved in distilled water that had been previously deoxygenated by bubbling $\mathrm{N}_{2}$ gas for $30 \mathrm{~min}$. The amount of the totally added iron powder was $3 \mathrm{~g}$ in $200 \mathrm{~mL}$ water. The solution was kept under $\mathrm{N}_{2}$ gas and vigorously stirred for $5 \mathrm{~min}$ in a water bath at $70^{\circ} \mathrm{C}$. Subsequently, a suspension containing $6 \mathrm{~g}$ kaolin was added thus, resulting in 6 $\mathrm{g}$ of kaolin per solution of the iron-salt and stirred for another $5 \mathrm{~min}$. Then, a solution of $\mathrm{NaOH}(5 \mathrm{M})$ was added drop-wise into the solution-mixture. After the addition of $\mathrm{NaOH}$, an initial brown precipitate was seen and thereafter a black precipitate was formed. Then, the titration was stopped when the $\mathrm{pH}$ value of the mixture attained a value of 9.0 and the mixture was aged for $60 \mathrm{~min}$ at $70^{\circ} \mathrm{C}$. The black precipitate was isolated by using an external magnetic field and the supernatant was decanted. The obtained solid magnetic-kaolinite MK part was quickly washed, four times, with deionized and then deoxygenated water and then dried at $50^{\circ} \mathrm{C}$ under air-oven. The prepared sample MK was kept in a vacuum desiccator and thereafter stored for adsorption experiment. 


\subsection{Characterization}

X-ray diffraction (XRD) or crystal phase of the samples used (NK and MK) were determined by Brucker-D Advance X-ray diffractometer using $\mathrm{CuK} \alpha(\lambda=$ $0.154060 \mathrm{~nm}$ ), radiation over $2 \theta$ interval of $10^{\circ}$ to $90^{\circ}$, with steps $0.02^{\circ}$ operated at $10 \mathrm{kV}$ and $30 \mathrm{~mA}$. Fourier transform infrared (FTIR) spectra of the samples were obtained on an IR-affinity-1 Shimadzu spectrophotometer (Japan). However, prior to this analysis, samples were prepared using $\mathrm{KBr}$-pressed-disk method. Surface morphology along its chemical composition examination of the sample were obtained by Zeiss LSM 510 Meta-field emission scanning electron microscope coupled with energy-disperse X-ray analyzer (FESEM-EDX), the magnetization was measured on a 7410 vibrating sample magnetometer (VSM) (Lake Shore Cryotronics Inc. United States), at room temperature.

\subsection{Kinetic study}

The adsorption of phosphate from the working phosphate solution $(30 \mathrm{mgP} / \mathrm{L})$ was studied by following this procedure: $0.5 \mathrm{~g}$ of each adsorbent was added into a beaker with $50 \mathrm{~mL}$ of $30 \mathrm{mgP} / \mathrm{L}$ phosphate solution. The sealed beakers were then put in a shaker bath at $25^{\circ} \mathrm{C}$ and agitated at $200 \mathrm{rpm}$ for $960 \mathrm{~min}(16 \mathrm{hr}) .10$ $\mathrm{mL}$ of dispersion was taken out over a given period of time $(0.5,1,2,3,5,10,20$, $30,60,120,180,240 \ldots 960 \mathrm{~min}$ ) and filtered using a membrane filter (pore size $0.45 \mathrm{~nm})$.

The concentration of phosphate in the filtrate was analyzed by molybdate blue-spectrophotometric method [21] and the amount of phosphate adsorbed onto the sample at different period $\left(q_{t}\right)$ was calculated using Equation (1):

$$
q_{t}=\frac{\left(C_{o}-C_{t}\right) \times V}{m}
$$

where $C_{o}$ and $C_{t}$ were phosphate concentrations in solution at initial and different time periods ( $\mathrm{mgP} / \mathrm{L}$ ) respectively. $V$, was the volume of solution (L) and $\mathrm{m}$, was the mass of adsorbent $(\mathrm{g})$.

In order to model the kinetic of the adsorption process the experimental data were fitted in the pseudo-first order (PFO), pseudo-second-order (PSO) [22] [23] [24] as represented by (Equation (2) and Equation (3)):

$$
\begin{gathered}
\log \left(q_{e}-q_{1}\right)=\log q_{e}-\frac{k_{1} t}{2.303} \\
\frac{t}{q_{t}}=\frac{1}{k_{2} q_{e}^{2}}+\frac{t}{q_{e}}
\end{gathered}
$$

where $t$ was the adsorption ( $\mathrm{min}), k_{1}(1 / \mathrm{min}), k_{2}(1 / \mathrm{min})$ were the adsorption rate constants of pseudo first and second order equations, respectively.

\subsection{Batch Adsorption Experiment}

The adsorption of phosphate from working phosphate solution $(30 \mathrm{mgP} / \mathrm{L})$ was determined using the following procedure: $0.5 \mathrm{~g}$ of adsorbent was added to 50 
$\mathrm{mL}$ of phosphate solution. This mixture was shaken on a constant temperature (room temperature) oscillator at $200 \mathrm{rpm}$. Then the solution was separated from the solid by magnetic separation. The residual phosphate concentration was determined by molybdate blue-spectrophotometric method [21]. The phosphate adsorption capacity $q_{e}$ (Equation (1)) (mg/g) or removal ratio $R$ (\%) (Equation (4)) was given from the following relationships:

$$
R=\left(C_{o}-C_{e}\right) \times \frac{100}{C_{o}} \%
$$

where $C_{o}$ and $C_{e}$ are the initial and equilibrium concentrations of phosphate solution $(\mathrm{mg} / \mathrm{L}) . m$ is the adsorbent dry weight $(\mathrm{g})$ and $v$ is the suspension volume (L).

The equilibrium data were fitted to the well-known Langmuir and Freundlich isotherm equations as shown in (Equation (5)) and (Equation (6)) respectively [25] [26].

Langmuir equation:

$$
q_{e}=q_{m} K_{L} \frac{C_{e}}{1+K_{L} C_{e}}
$$

Freundlich equation:

$$
q_{e}=K_{f} C_{e}^{\frac{1}{n}}
$$

where $C_{e}(\mathrm{mg} \mathrm{P} / \mathrm{L})$ and $q_{e}(\mathrm{mg} \mathrm{P} / \mathrm{g})$ were phosphate concentration and corresponding adsorption capacity at the equilibrium. $q_{m}(\mathrm{mg} \mathrm{P} / \mathrm{g}$ ) was the maximum adsorption capacity and $K_{L}$ was the Langmuir adsorption equilibrium constant, which were related to adsorption capacity and energy or net enthalpy of adsorption. $K_{F}$ and $\mathrm{n}$ were the constants in the Freundlich isotherm equation, which measured the adsorption capacity and intensity respectively.

\subsubsection{Effect of Solution $\mathrm{pH}$}

Effect of $\mathrm{pH}$ on phosphate adsorption was studied at different $\mathrm{pH}$ (varying from 2 to 12). In this case, the solution $\mathrm{pH}$ was adjusted by adding $0.1 \mathrm{M} \mathrm{NaOH}$ or $\mathrm{HCl}$ solution; and the adsorbent dose or solid/liquid ratio, volume of phosphate solution, concentration of phosphate, contact time, and temperature were set at $0.5 \mathrm{~g}, 50 \mathrm{~mL}, 30 \mathrm{mgP} / \mathrm{L}, 960 \mathrm{~min}$, and $27^{\circ} \mathrm{C}$, respectively.

\subsubsection{Effect of Solid/Liquid Ratio}

Effect of adsorbent dose or solid/liquid ratio on phosphate adsorption was studied at different dose (varying from 0.1 to $0.5 \mathrm{~g}$ ). In this case, the solution $\mathrm{pH}$, volume of phosphate solution, concentration of phosphate, contact time, and temperature were set at $4,50 \mathrm{~mL}, 30 \mathrm{mgP} / \mathrm{L}, 960 \mathrm{~min}$, and $27^{\circ} \mathrm{C}$, respectively.

\subsubsection{Zero Point of Charge Determination (ZPC)}

The zpc of was determined by introducing a fixed mass of adsorbents into 100 $\mathrm{mL}$ Erlenmeyer flask containing $50 \mathrm{~mL}$ of $0.01 \mathrm{M}$ potassium nitrate solution. The initial $\mathrm{pH}$ of these solutions was adjusted to $2,3,4,5,6,7,8,9,10$ and 12 by 
adding few drops of either nitric acid or potassium hydroxide. After a contact time of $48 \mathrm{~h}$, the final $\mathrm{pH}$ was measured, and plotted against the initial $\mathrm{pH}$ [27] [28].

\section{Results and Discussion}

\subsection{XRD Analysis}

Figure 1(a) \& Figure 1(b) showed the XRD patterns of natural kaolin (NK) and magnetically-modified kaolin (MK) respectively. There was a significant difference in the XRD patterns of natural kaolin powder (NK) and magnetically-modified kaolin (MK) due to the incorporation of $\mathrm{Fe}_{3} \mathrm{O}_{4}$ into the clay framework.

Basically, the typical diffraction angles of kaolin at $2 \theta=12.20^{\circ}, 20.23^{\circ}, 24.82^{\circ}$, $38.28^{\circ}, 45.74^{\circ}$, were observed in natural kaolin (NK). This result was in favorable

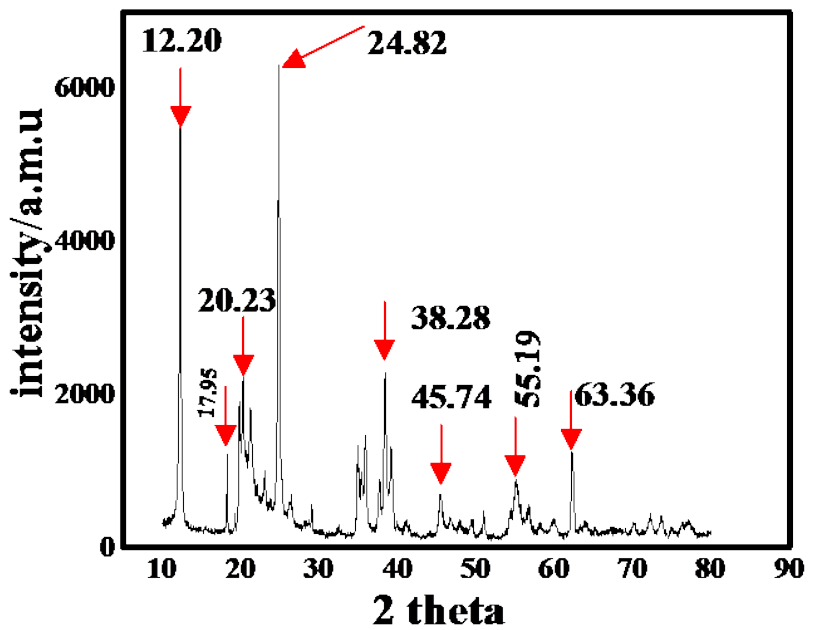

(a)

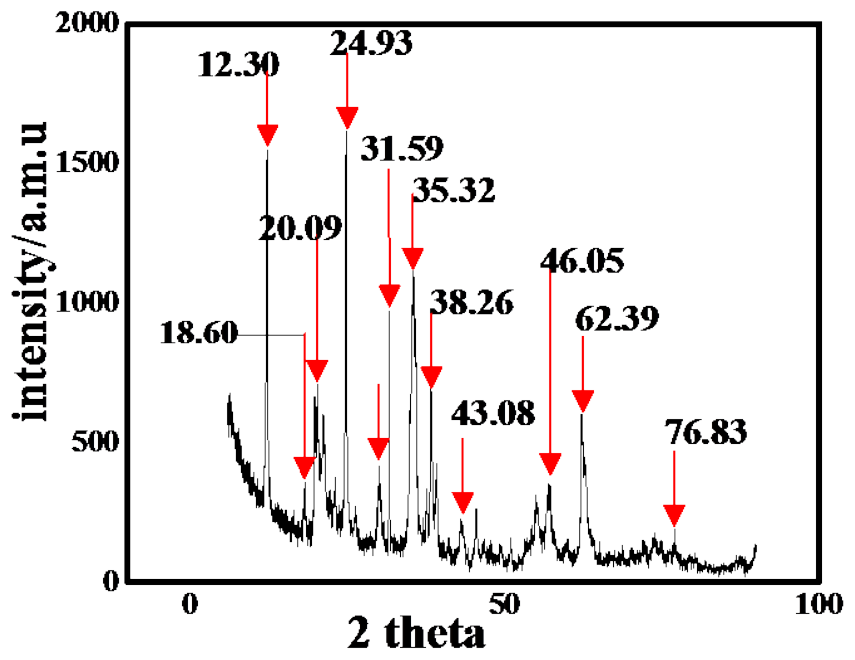

(b)

Figure 1. (a) XRD spectra of natural kaolin (NK); (b) XRD spectra of natural kaolin (MK). 
comparison with the standard pattern of kaolin as reported by [13] [29]. In contrast, the XRD pattern of MK (Figure 1(b) revealed the presence of $\mathrm{Fe}_{3} \mathrm{O}_{4}$ and the following peaks were observed: at $2 \theta=18.60^{\circ}, 31.59^{\circ}, 35.32^{\circ}, 43.08^{\circ}, 62.39^{\circ}$, corresponding to the peaks of $\mathrm{Fe}_{3} \mathrm{O}_{4}$ [17]. This is a confirmation the existence of the pure phase of $\mathrm{Fe}_{3} \mathrm{O}_{4}$ [30] on the kaolin mineral. The modified kaolin showed some traces of parent kaolin, which was an indication that the entire surface was not covered up by $\mathrm{Fe}_{3} \mathrm{O}_{4}$.

\subsection{Spectroscopy Analysis}

The FT-IR analysis of NK, MK and PMK (post-adsorption MK) are shown in Figures $2(\mathrm{a})-(\mathrm{c})$. The areas specified by Circle, arrow and triangle were where specific absorption bands synonymous with natural kaolin, magnetite and P-laden clay were observed. The absorption bands at $3687 \mathrm{~cm}^{-1}$ and $3617 \mathrm{~cm}^{-1}$ were attributed to the $\mathrm{OH}$ of water molecules. Another absorption band, corresponding to water deformation was observed at $1631 \mathrm{~cm}^{-1}$ [12] [31] [32] [33]. The characteristics absorption peaks, around $3687 \mathrm{~cm}^{-1}$ and $1631 \mathrm{~cm}^{-1}$ were observed in all the spectra. This was ascribed to the stretching vibration of $\mathrm{O}-\mathrm{H}$ bond and the bending vibration of $\mathrm{H}-\mathrm{O}-\mathrm{H}$ from water molecules, adsorbed on the external surface of the sample during handling. The bands at $3687 \mathrm{~cm}^{-1}$ was assigned to the stretching vibration of hydroxyl groups attached to octahedral $\mathrm{Mg}^{2+}$ ions located in the interior blocks of NK [34]. The band at $3688 \mathrm{~cm}^{-1}$ was ascribed to the cation-coordinated $(\mathrm{Mg}, \mathrm{Al})$ water [32].

Other vibration bands at $917 \mathrm{~cm}^{-1}, 912 \mathrm{~cm}^{-1}$, and $420 \mathrm{~cm}^{-1}$ to $500 \mathrm{~cm}^{-1}$ were assigned to $\mathrm{X}-\mathrm{O}(\mathrm{X}=\mathrm{Si}, \mathrm{Al})$ stretching and bending modes. Other absorption bands that ranged between 550 and $590 \mathrm{~cm}^{-1}$ were attributed to the stretching bond of Fe-O, primarily from $\mathrm{Fe}_{3} \mathrm{O}_{4}$ [35] [36]. This bond showed that the magnetite was successfully loaded on the kaolin clay mineral. After the adsorption of phosphate, a new shift in peak appeared between 900 and $1050 \mathrm{~cm}^{-1}$. This peak

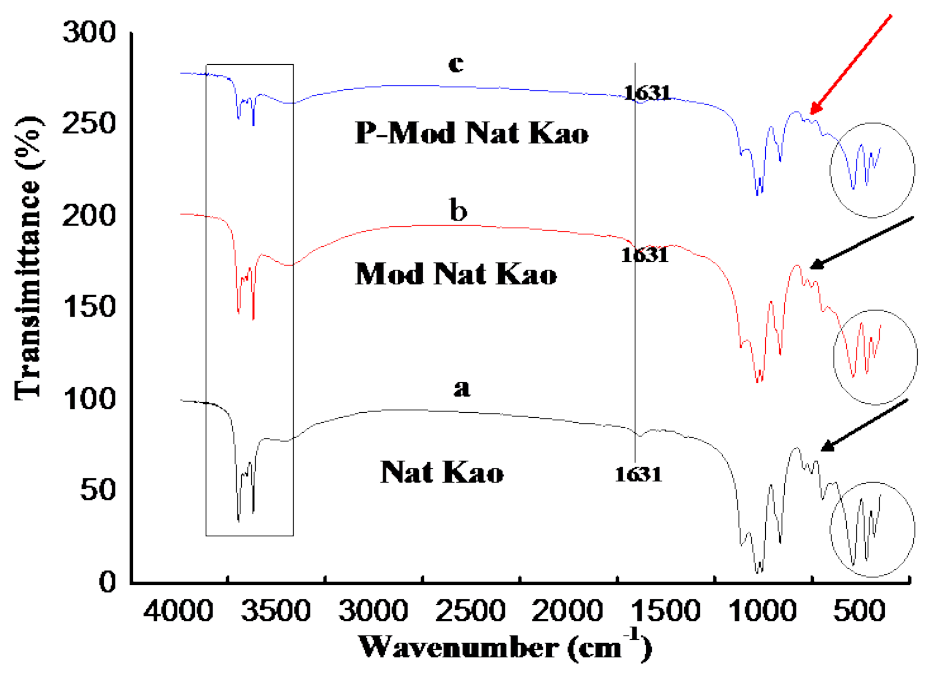

Figure 2. FTIR spectra of (a) natural kaolin (NK); (b) magnetic kaolin (MK) and (c) P-laden magnetic kaolin. 
was not intensive as a result of not too large capacity of adsorption [35]. However, this peak was assigned to the asymmetry vibration of $\mathrm{P}-\mathrm{O}$ bond. This indicated that the surface hydroxyl groups were replaced by the adsorbed phosphate [35].

\subsection{Field-Emission Scanning Electron Microscope}

The FESEM images of NK and MK are shown in Figure 3(a) \& Figure 3(b). The FESEM image is shown alongside with the results of the elemental analysis. Figure 3(a) showed a smooth surface with linear ridges of NK. Figure 3(b) as well showed a rough surface with oval ridges and micro pores of MK. The rough surface of MK was a confirmation of successful modification by iron oxide of NK, which were loaded more on the NK surface. Additional confirmation of the modification was the higher Fe-metal composition of the chemical analysis shown by Figure 4(a) \& Figure 4(b).

\subsection{Magnetization Analysis}

The magnetization curve shown in Figure 5 was the curve from a number iron salts precursors and an ordered iron (II/III) to iron (III/II) ratio. However, the

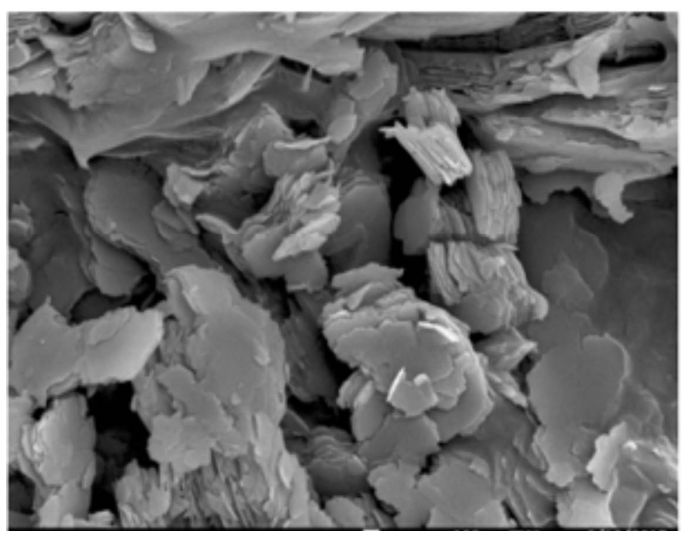

(a)

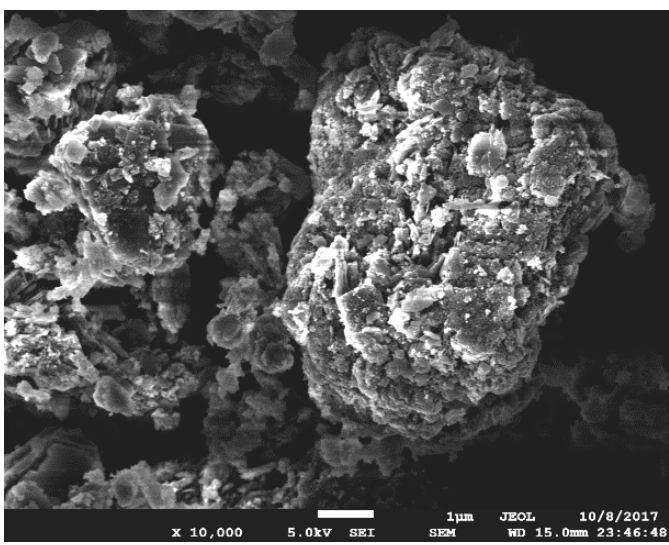

(b)

Figure 3. (a) FESEM pattern of natural kaolin (NK); (b) FESEM pattern of modified kao$\operatorname{lin}(\mathrm{MK})$. 


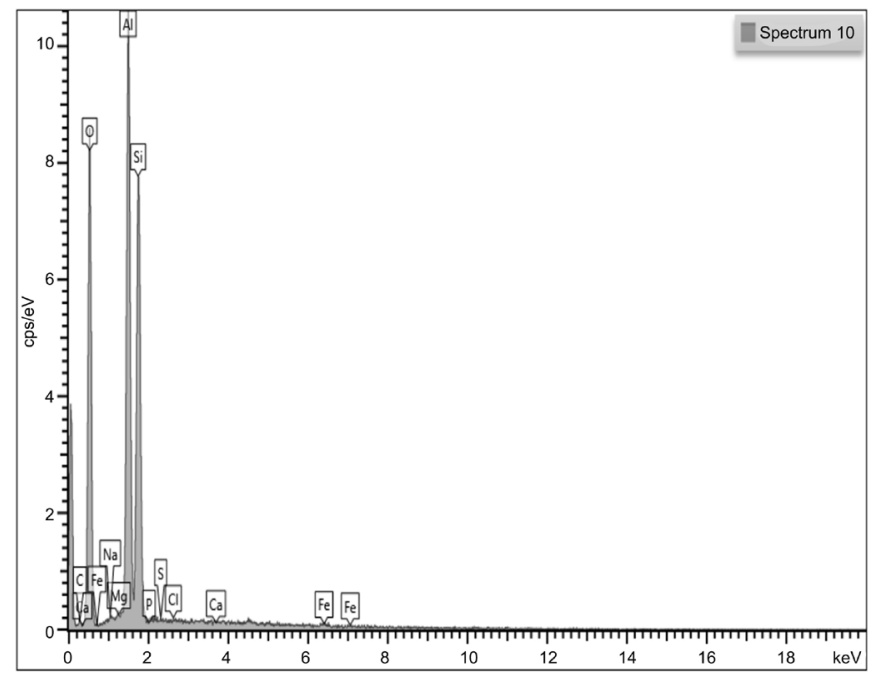

(a)

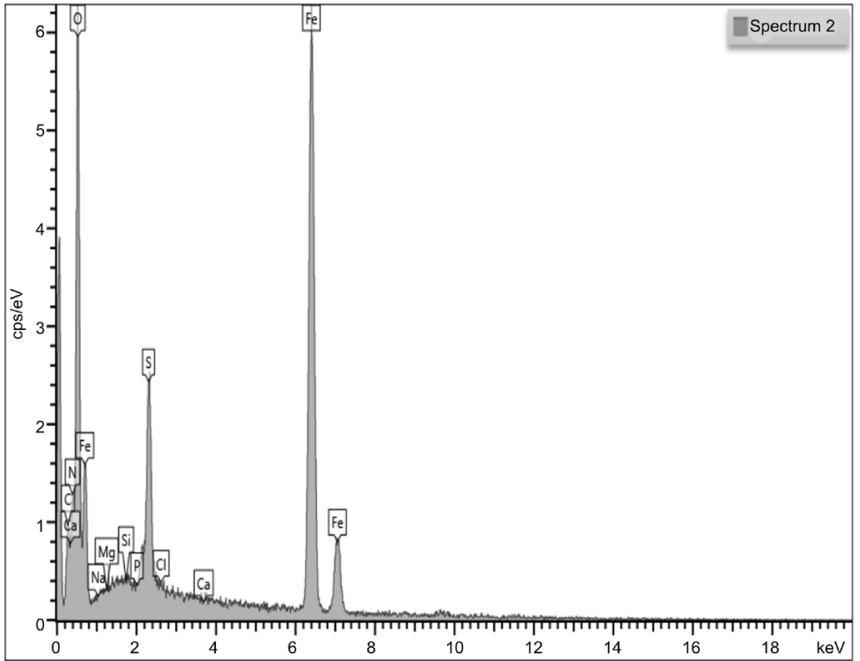

(b)

Figure 4. (a) EDX spectra of natural kaolin (NK); (b) EDX spectra of magnetic modified kaolin (MK).

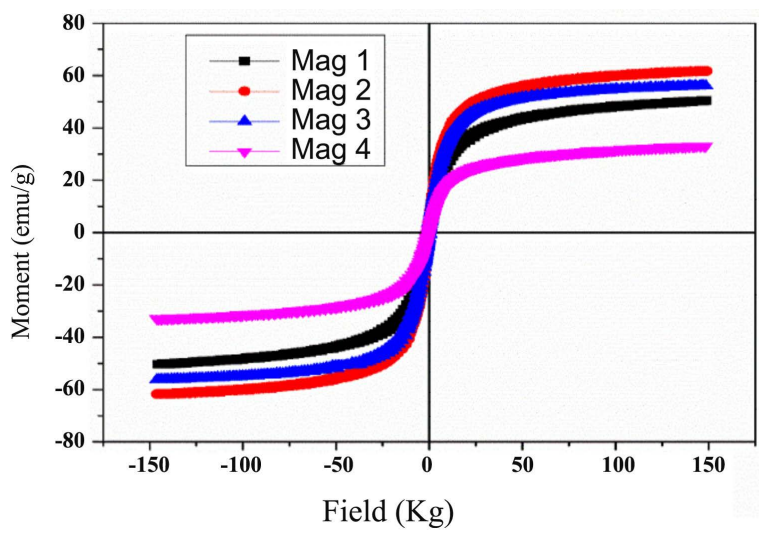

Figure 5. Magnetic hysteresis loop: (1) magnetite $\left(\mathrm{Fe}_{3} \mathrm{O}_{4}\right)$ of Fe-sulfate salts precursor; (2) magnetite $\left(\mathrm{Fe}_{3} \mathrm{O}_{4}\right)$ of $\mathrm{Fe}$-chloride salts precursor; (3) magnetite $\left(\mathrm{Fe}_{3} \mathrm{O}_{4}\right)$ of $\mathrm{Fe}$-(chloride/sulfate) salts precursor; (4) magnetite $\left(\mathrm{Fe}_{3} \mathrm{O}_{4}\right)$ of $\mathrm{Fe}$-(sulfate/chloride)-salts precursor. 
curve showed the saturation magnetizations (Ms) in a decreasing order of iron (II/III) chloride-chloride salt $(61.739 \mathrm{emu} / \mathrm{g})>$ iron (II/III) chloride-sulfate salt $(56.185 \mathrm{emu} / \mathrm{g})>$ iron $(\mathrm{II} / \mathrm{III})$ sulfate-sulfate salt $(50.311 \mathrm{emu} / \mathrm{g})>$ iron $(\mathrm{III} / \mathrm{II})$ sulfate-chloride salt $(33.039 \mathrm{emu} / \mathrm{g})$, the individual curve in the mentioned order was represented as; mag. 2, mag. 3, mag. 1 and mag. 4 respectfully. The magnetite $\left(\mathrm{Fe}_{3} \mathrm{O}_{4}\right)$ with the highest saturation magnetization (mag. 2) was subsequently used in the preparation for magnetic-kaolin composite (MK). Thus, the high saturation magnetization would guarantee quick response of the MK to external magnetic source [36]. Figure 6 showed the magnetic hysteresis of the magnetite with highest magnetization saturation (mag. 2) and its subsequent kaolinite modified form represented as Kmag. 2 in the curve. It was observed that the saturation magnetization value of $\mathrm{MK}(19,009 \mathrm{emu} / \mathrm{g})$ was far less than that of the corresponding magnetite $\left(\mathrm{Fe}_{3} \mathrm{O}_{4}\right)$. The magnetic separation properties of $\mathrm{NK}$ and MK were tested and the result showed that the MK can be re-collected by magnet, whereas the NK remained dispersed in solution (Figure 7). However, the

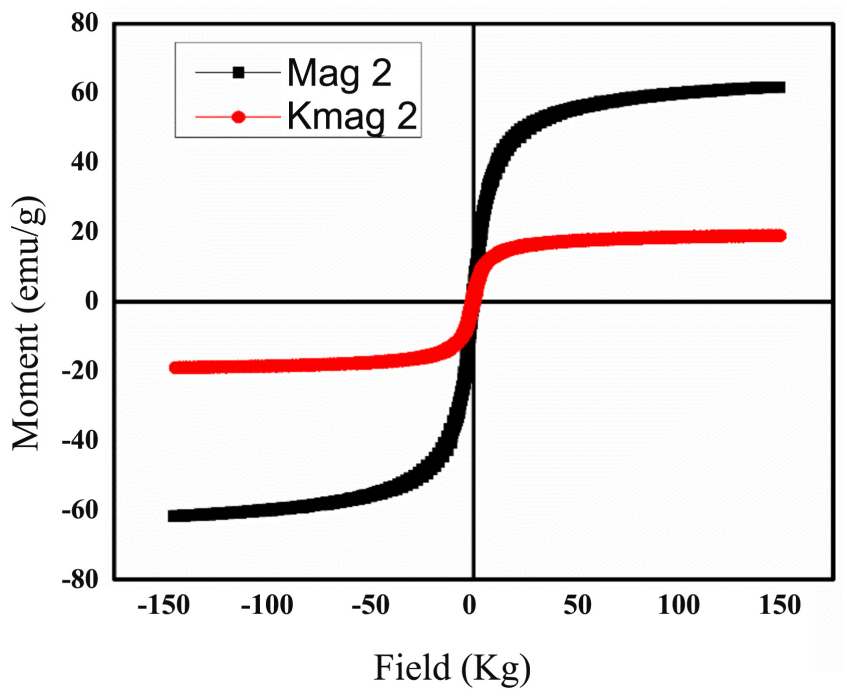

Figure 6. Magnetic hysteresis of magnetite $\left(\mathrm{Fe}_{3} \mathrm{O}_{4}\right)$ of chloride $\left(\mathrm{Cl}^{-}\right)$salts (Mag 2) magnetically-modified kaolin (Kmag 2).

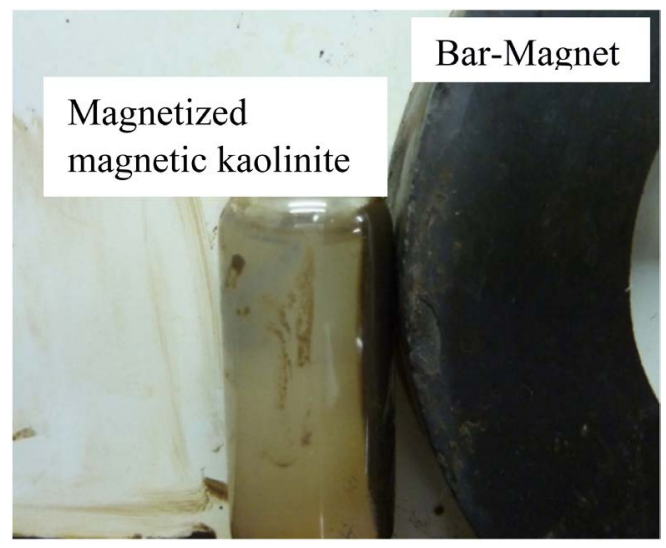

Figure 7. Digital imagery of magnetized magnetic-kaolin (MK). 
method of magnetization was devoid of subjective gravitational pull of the material, see Figure 7. This feature will make MK more attractive as an adsorbent in practical application.

\subsection{Adsorption Kinetic}

The phosphate adsorption capacity of the adsorbents (NK, MK), as a function of time is shown in Figure 8(a) \& Figure 8(b). The phosphate adsorption was rapid at the first stage of the adsorption process and the capacity reduced over time until the equilibrium adsorption capacity was attained. The adsorption equilibrium was attained at $960 \mathrm{~min}$.

The adsorption kinetic was fitted to the pseudo-first-order and pseudo-second-order kinetic equations. The corresponding parameters and correlation coefficients $\left(R^{2}\right)$ values are listed in Table 1 . The results showed that pseudo-second order equation fitted the experimental data better than the pseudo first order equation, The $R^{2}=0.9806$ for the sample NK, $R^{2}=0.9776$ for the sample MK suggested that the phosphate adsorption onto NK and MK occurred through chemisorption mode of adsorption [37]. The results of this study agreed

$\approx 2.31 \mathrm{mg} / 10.99 \mathrm{mg} / \triangle 9.74 \mathrm{mg} / 19.34 \mathrm{mg} / \square 31.60 \mathrm{mg} /$

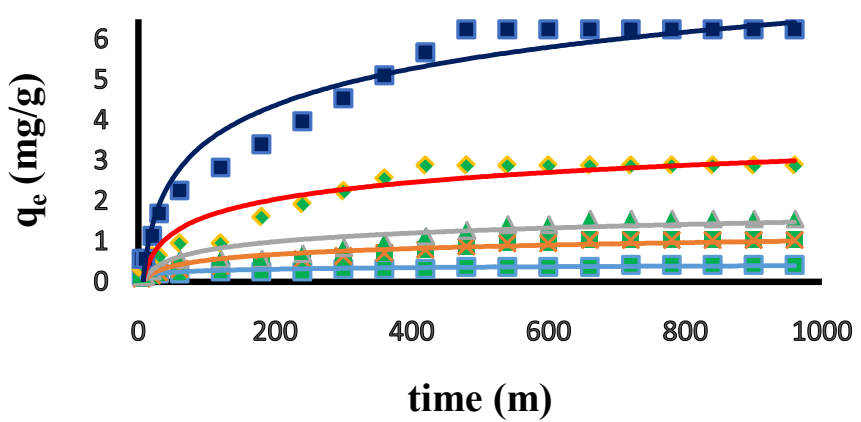

(a)

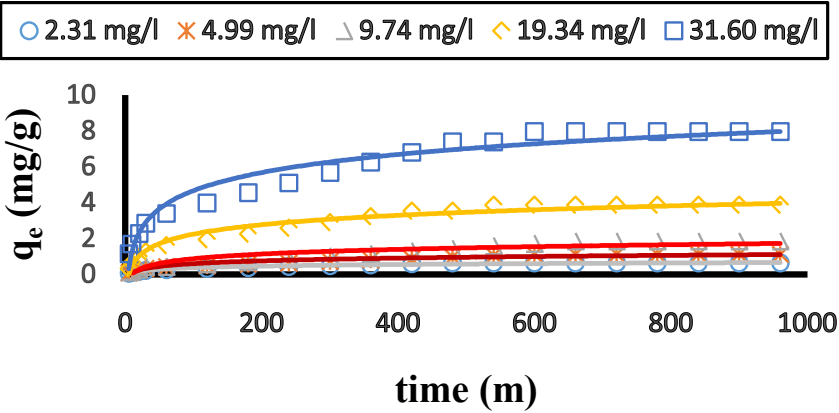

(b)

Figure 8. (a) Adsorption kinetic of phosphate on natural kaolin (NK). Conditions: Adsorbent dose $=1 \mathrm{~g} / \mathrm{L}$; contact time $=960 \mathrm{~m}$; initial phosphate concentration $=$ varied; agitation speed $=200 \mathrm{rpm}$; Temperature $=290 \mathrm{~K}$; (b) Adsorption kinetic of phosphate on magnetic-modified natural kaolin $(\mathrm{MK})$. Conditions: Adsorbent dose $=1 \mathrm{~g} / \mathrm{L}$; contact time $=960 \mathrm{~m}$; initial phosphate concentration $=$ varied; agitation speed $=200 \mathrm{rpm}$; Temperature $=290 \mathrm{~K}$. 
with other studies [38] [39] [40]. The sample MK exhibited an enhanced phosphate removal efficiency ( $7.38 \mathrm{mg} \mathrm{P} / \mathrm{g}$ for $\mathrm{NK}$ and $\sim 9.08 \mathrm{mgP} / \mathrm{g}$ for $\mathrm{MK}$ ).

\subsection{Adsorption Isotherm}

The adsorption isotherm data were fitted to the Langmuir and Freundlich equilibrium isotherm equations. The linear plots of Langmuir and Freundlich for phosphate adsorption onto NK and MK are shown in Figure 9(a) \& Figure 9(b) and Figure 10(a) \& Figure 10(b).

The fitted constants for the two isotherm equations are presented in Table 2. The experimental data for natural and modified kaolin was better described by Langmuir and Freundlich respectively, as expressed by $\mathrm{R}^{2}$ values obtained, see Table 2. Based on the values of $q_{m}$ the phosphate adsorption capacity was higher

Table 1. Adsorption kinetic parameter.

\begin{tabular}{ccccc}
\hline \multirow{2}{*}{ Sample } & \multicolumn{2}{c}{ Pseudo-first order } & \multicolumn{2}{c}{ Pseudo-second order } \\
\cline { 2 - 5 } & $K_{1}$ & $R^{2}$ & $K_{1}$ & $R^{2}$ \\
\hline NK & 0.0020 & 0.7875 & 0.0009 & 0.9806 \\
MK & 0.0023 & 0.8573 & 0.0009 & 0.9776 \\
\hline
\end{tabular}

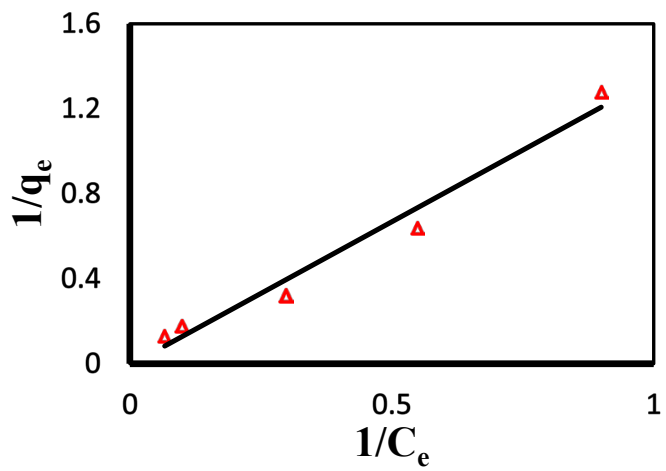

(a)

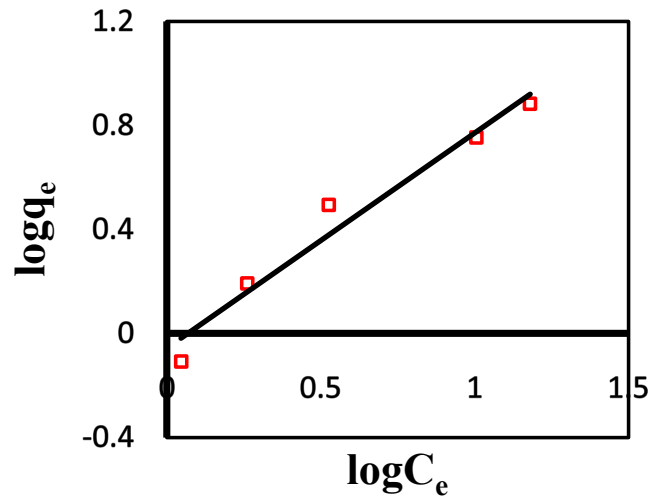

(b)

Figure 9. (a) Langmuir plot of NK (condition: adsorbent: 0.1 (g); Phosphate concentrations: varied mg/L Vol: $50 \mathrm{~mL}$; T: $293 \mathrm{~K}$ ); (b) Freundlich plot of NK (condition: adsorbent: 0.1 (g); Phosphate concentrations: varied mg/L Vol: $50 \mathrm{~mL}$; $293 \mathrm{~K}$ ). 
Table 2. Langmuir and Freundlich equation parameters of phosphate adsorption onto $\mathrm{NK}$ and MK.

\begin{tabular}{cccc}
\hline Model & Parameter & NK & MK \\
\hline \multirow{3}{*}{ Freundlich } & $K_{f}$ & 0.88 & 1.63 \\
& $\frac{1}{n}$ & 0.8272 & 0.9107 \\
& $R^{2}$ & 0.9729 & 0.9586 \\
& $R^{2}$ & 0.9813 & 0.9519 \\
Langmuir & $K_{L}$ & 0.05 & 0.011 \\
& $q_{m}$ & 17.61 & 52.91 \\
\hline
\end{tabular}

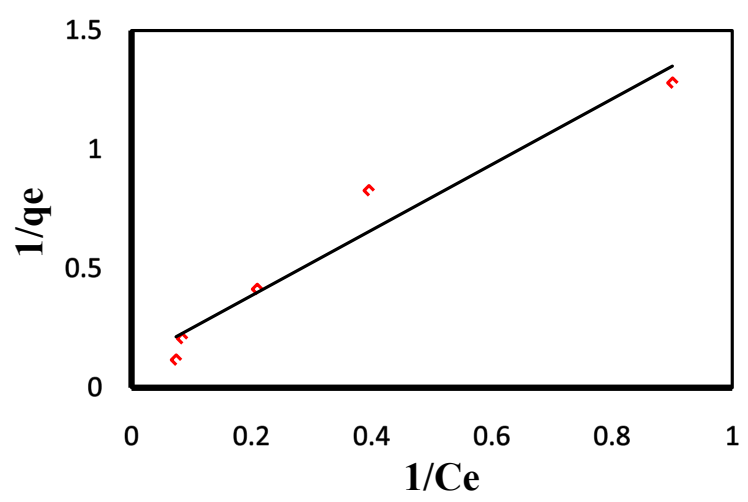

(a)

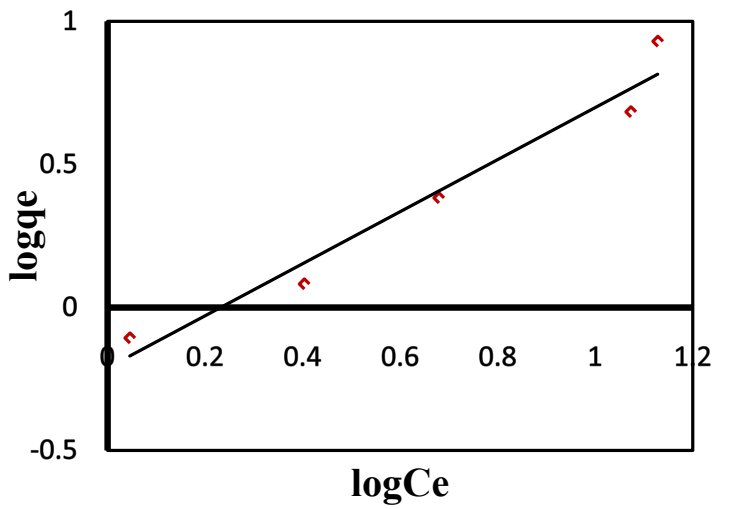

(b)

Figure 10. (a) Langmuir plot of MK (condition: adsorbent: 0.1 (g); Phosphate concentrations: varied mg/L Vol: $50 \mathrm{~mL}$; T: $293 \mathrm{~K}$ ); (b) Freundlich plot of MK (condition: adsorbent: 0.1 (g); Phosphate concentrations: varied mg/L Vol: $50 \mathrm{~mL}$; T: $293 \mathrm{~K}$ ).

in MK than in NK. The enhanced performance was attributed to the high surface area exhibited by magnetic material [15]. A comparison of other magnetic adsorbents with the one (MK) in the present study affirmed the improvement of adsorption capacity by MK. There was also: relative improvement in the magnetic condition guaranteed by the special precursor salts of particular iron ratio used in the present study. Table 3 indicated that MK was best in phosphate adsorption among other magnetic materials used in previous studies. 
Table 3. Comparison of the phosphate adsorption capacity of various magnetic-adsorbents.

\begin{tabular}{ccc}
\hline Adsorbent & Ads. Cap. $(\mathrm{mg} / \mathrm{g})$ & Ref \\
\hline $\mathrm{Fe}_{3} \mathrm{O}_{4} @ \mathrm{Zn}$-Al-LDH & 36.9 & Zaidi et al., 2014 \\
$\mathrm{Fe}_{3} \mathrm{O}_{4} @ \mathrm{Mn}$-Al-LDH & 31.7 & Zaidi et al., 2014 \\
$\mathrm{Fe}_{3} \mathrm{O}_{4} @ \mathrm{Ni}$-Al-LDH & 26.5 & Zaidi et al., 2014 \\
$\mathrm{Fe}_{3} \mathrm{O}_{4}-\mathrm{Fe} / \mathrm{Mn}$ & 6.8 & Long et al., 2011 \\
$\mathrm{Fe}_{3} \mathrm{O}_{4}-\mathrm{Sand}$ & 1.5 & Biswas et al., 2008 \\
$\mathrm{Fe}_{3} \mathrm{O}_{4}-\mathrm{ATP}$ & 16.6 & Pan et al., 2011 \\
$\mathrm{Fe}_{3} \mathrm{O}_{4}-\mathrm{MMT}$ & 18.8 & Peng et al., 2006 \\
$\mathrm{Fe}_{3} \mathrm{O}_{4}-\mathrm{SEP}$ & 20.5 & Liu et al., 2014 [13] \\
$\mathrm{Fe}_{3} \mathrm{O}_{4}-$ Zeolite & 18.9 & Bourlinos et al., 2003 \\
Iron oxide-doped activated carbon & 14.1 & Wang et al., 2008 \\
An hydrous iron-oxide & 29.5 & Zeng et al., 2004 \\
Iron hydroxide eggshell & 2.02 & Mezenner et al., 2009 \\
Fe & & This study \\
\hline
\end{tabular}

\subsubsection{Effect of Point Zero Charge (PZC)}

The pzc of Nk was reviewed from literatures due to the fact that kaolin has been severally used. The pzc of NK was 6.9 [13] [27]. The pzc of Mk was 7.8 as shown in Figure 11. It was obvious from these results that $\mathrm{NK}$ has a pzc value less than the value for $\mathrm{MK}$, which suggest that the introduction of $\mathrm{Fe}_{3} \mathrm{O}_{4}$ particles in kaolin is favorable to improve surface electrochemical properties. The increment is also due to the specific adsorption of iron ions on MK composite. The phenomenon of iron leaching from magnetite clay-composite has been observed by another authors; Oliveira [41]. In adsorbent solution, the presence of $\mathrm{Fe}(\mathrm{II})$ or $\mathrm{Fe}(\mathrm{III})$ ions even, at small amount can shift the pzc of magnetite $\mathrm{Fe}_{3} \mathrm{O}_{4}$ to higher $\mathrm{pH}$ values. And, the higher the iron ions concentration, the larger is the shift of pzc toward higher $\mathrm{pH}$ [13]. Consequently, when the $\mathrm{pH}$ of aqueous solution is below the pzc, the surface of the adsorbent will become positively charged. At $\mathrm{pH}$ above pzc, the surface of the adsorbent is negatively charged and there is strong electrostatic attraction between surface group and phosphate moieties.

\subsubsection{Effect of $\mathrm{pH}$}

The effects of solution $\mathrm{pH}$ value on the adsorption of phosphate from aqueous solution, using magnetic kaolin composite were investigated and the results are presented in Figure 12. It was discovered that for most phosphate concentrations used in this study, the equilibrium $\mathrm{pH}$ values were higher than the initial $\mathrm{pH}$ (i.e. initial pHs 3.97 to 10.08) but, lower than the initial $\mathrm{pH}$ at 12.01. This effect could be attributed to the acid-base properties of hydroxyl groups on the adsorbent surface and the phosphate species in solution which resulted into protonation and deprotonation of the material surface. However, the highest adsorption $\mathrm{pH}$ for the material studied (MK) was 4 . 


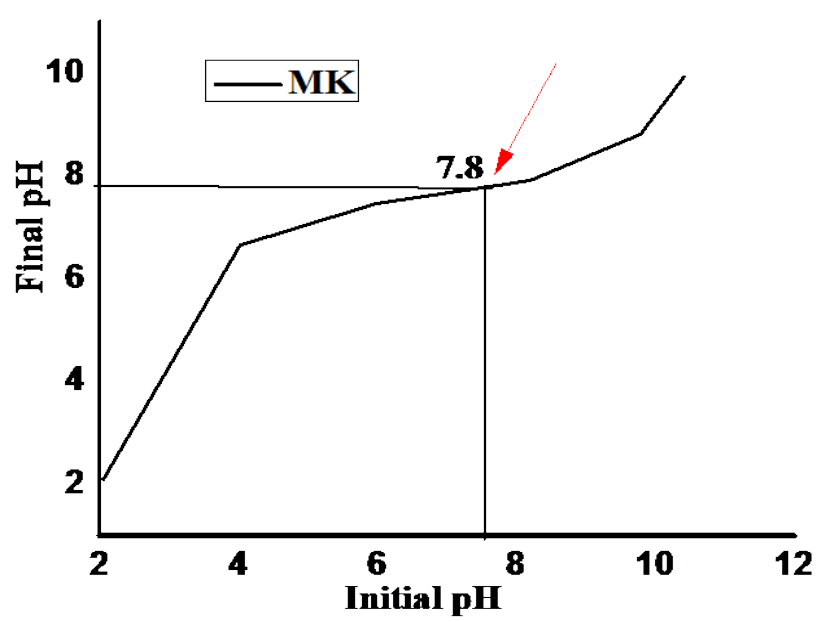

Figure 11. Point of zero charge of magnetic-kaolin (Mk).

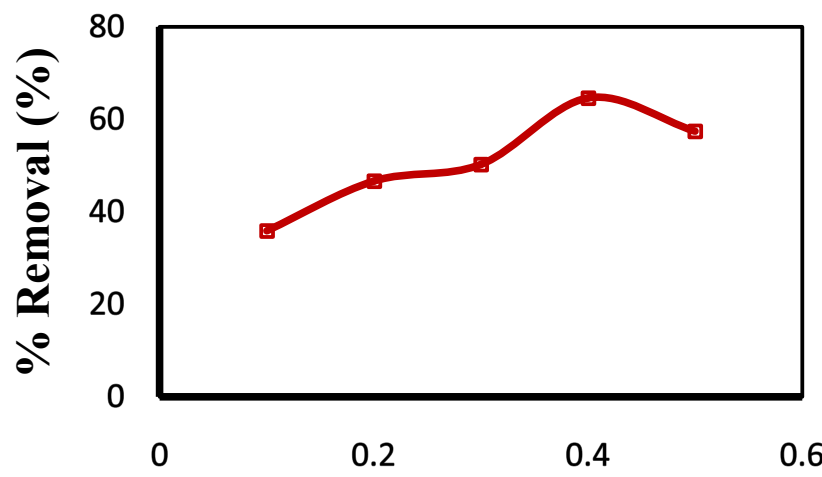

Ads. Dosage (g)

Figure 12. Effect of Adsorbent dosage on the phosphate ion adsorption by MK.

\subsubsection{Effect of Adsorbent Dose}

The effect of adsorbent dose was shown in Figure 13. The figure showed that as the adsorbent dose increases from $0.1 \mathrm{~g}$ to $0.5 \mathrm{~g}$, the phosphate removal efficiency increased from $35 \%$ to $64 \%$ for MK. This can be explained by progressive increase of available binding site for phosphate adsorption by the material. However, any increase beyond $0.4 \mathrm{~g} / 50 \mathrm{~mL}$, did not increase the \% removal of phosphate. This reduction in the adsorbent removal capacity could be as a result of the following reasons: the increase in adsorbent dosage with fixed phosphate concentration $(30 \mathrm{mg} / \mathrm{L}$ ) and fixed volume of the adsorbate (phosphate) could lead to unsaturation of sorption sites through the sorption process [42] [43]. Further increase of the adsorbent dosage could cause adsorbent particle interaction which might result in sorbent surface aggregation [42]. This eventually might lead to reduction in the adsorbent surface area. Thus, this result was confirmed by the work of Zeng [44].

\section{Conclusion}

In this study, two different clay-adsorbents were used while one was magnetic in 


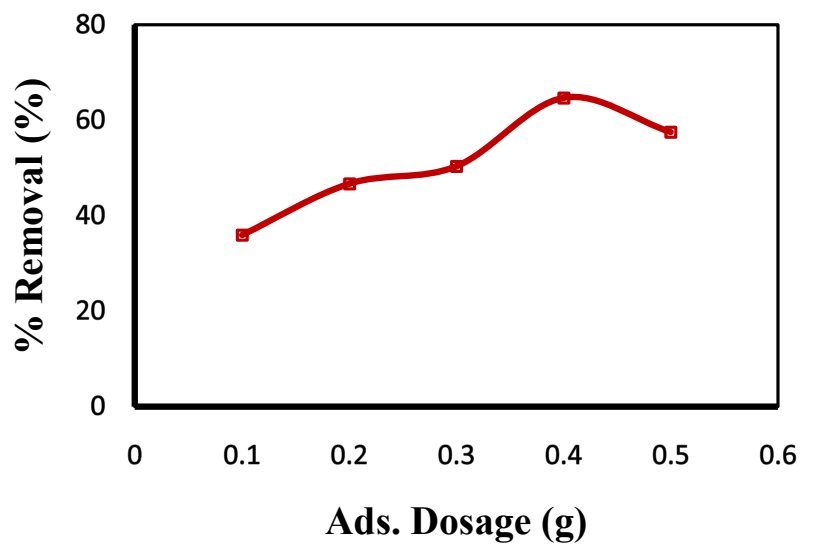

Figure 13. Effect of adsorbent dose on the phosphate adsorption by MK (condition: adsorbent: varied (g); Phosphate concentrations: $30 \mathrm{mg} / \mathrm{L}$ Vol: $50 \mathrm{~mL}$; T: $293 \mathrm{~K}$ ).

nature and developed by a rapid co-precipitation method and, the other was naturally existing kaolin (NK). The two adsorbents were used for phosphate adsorption from aqueous solution. The adsorbents were characterized by XRD, FTIR FESEM-EDAX and VSM analyses. Characterization results proved the successful synthesis of magnetic-clay material. Adsorption experiment was carried out as a function of adsorbent dosage and initial $\mathrm{pH}$ of phosphate solution. However, the sorption capacity of the adsorbent was gradually increased as the sorbent dose increased, although this gradual increase was unnoticed at further increase from 0.4 to $0.5 \mathrm{~g}$ dosage. This effect of $\mathrm{pH}$ could be attributed to the acid-base properties of hydroxyl groups on the adsorbent surface and the phosphate species in solution which resulted in protonation and deprotonation of the material surface. Hence, the maximum adsorption of the phosphate species was more obvious at $\mathrm{pH}$. The maximum adsorption capacity of phosphate compared with the un-magnetized raw kaolin increased from 17.61 to $52.91 \mathrm{mg} / \mathrm{g}$ after modification by iron-oxide. The Langmuir isotherm best described the NK experimental data while Freundlich described the treated/modified kaolin (MK). Based on the present investigation, it could be concluded that the magnetically treated kaolin can be used efficiently in the removal of phosphate from aqueous solution.

\section{Acknowledgements}

The Authors acknowledge Adekunle Ajasin University Akungba Akoko (AAUA) and Indian Institute of Technology, Guwahati (IIT-G), India, for the facilities provided for the successful completion of this research work.

\section{Conflicts of Interest}

The authors declare no conflicts of interest regarding the publication of this paper.

\section{References}

[1] Liu, Y., Xu, L., Liu, J.S., Liu, X.Y., Chen, C.H., Li, G.Y. and Meng, Y.F. (2016) Gra- 
phene Oxides Cross-Linked with Hyper Branched Poly-Ethylenimines: Preparation, Characterization and Their Potential as Recyclable and Highly Efficient Adsorption Materials for Lead (II) Ions. Chemical Engineering Journal, 285, 698-708.

https://doi.org/10.1016/j.cej.2015.10.047

[2] Dong, L.J., Zhu, Z.L., Qiu, Y.L. and Zhao, J.F. (2016) Removal of Lead from Aqueous Solution by Hydroxyapatite/Manganese Dioxide Composite. Frontiers of Environmental Science \& Engineering, 10, 28-36.

https://doi.org/10.1007/s11783-014-0722-5

[3] Ye, H., Chen, F., Sheng, Y., Sheng, G. and Fu, J. (2006) A Novel Lanthanum-Modified Bentonite, Phoslock, for Phosphate Removal from Wastewaters. Separation and Purification Technology, 50, 283-290. https://doi.org/10.1016/j.seppur.2005.12.004

[4] Khosa, A.M., Shah, S.S. and Feng, X. (2014) Metal Sericin Complexation and Ultrafiltration of Heavy Metals from Aqueous Solution. Chemical Engineering Journal, 244, 446-456. https://doi.org/10.1016/j.cej.2014.01.091

[5] Jung, C., Phal, N., Oh, J., Chu, K.H., Jang, M. and Yoon, Y. (2015) Removal of Humic and Tannic Acids by Adsorption-Coagulation Combined Systems with Activated Biochar. Journal of Hazardous Materials, 300, 808-814.

https://doi.org/10.1016/j.jhazmat.2015.08.025

[6] Pu, Y.B., Yang, X.F., Zheng, H., Wang, D.S., Su, Y. and He, J. (2013) Adsorption and Desorption of Thallium(I) on Multiwalled Carbon Nanotubes. Chemical Engineering Journal, 219, 403-410. https://doi.org/10.1016/j.cej.2013.01.025

[7] Guo, H.M., Yang, L.J. and Zhou, X.Q. (2014) Simultaneous Removal of Fluoride and Arsenic from Aqueous Solution Using Activated Red Mud. Separation Science and Technology, 49, 2412-2425. https://doi.org/10.1080/01496395.2014.922579

[8] Chan, B. and Dudeney, A. (2008) Reverse Osmosis Removal of Arsenic Residues from Bioleaching of Refractory Gold Concentrates. Minerals Engineering, 21, 272-278. https://doi.org/10.1016/j.mineng.2007.10.003

[9] Tran, H.H., Roddick, F.A. and O’Donnell, J.A. (1999) Comparison of Chromatography and Desiccant Silica Gels for the Adsorption of Metal Ions-I. Adsorption and Kinetics. Water Research, 33, 2992. https://doi.org/10.1016/S0043-1354(99)00017-2

[10] Mohanty, K., Das, D. and Biswas, M.N. (2006) Preparation and Characterization of Activated Carbons from Sterculia alata Nutshell by Chemical Activation with Zinc Chloride to Remove Phenol from Wastewater. Adsorption, 12, 119. https://doi.org/10.1007/s10450-006-0374-2

[11] Akpomie, K.G. and Dawodu, F.A. (2014) Efficient Abstraction of Nickel(II) and Manganese(II) Ions From Solution Unto an Alkaline Modified Montmorillonite. Journal of Taibah University for Science, 8, 343-356.

https://doi.org/10.1016/j.jtusci.2014.05.001

[12] Asuha, S., Gao, Z., Li, X., Wu, H., Zhao, S.M. and Deligeer, W. (2015) Magnetic Modification of Acid-Activated Kaolin: Synthesis, Characterization, and Adsorptive Properties. Microporous and Mesoporous Materials, 202, 1-7. https://doi.org/10.1016/j.micromeso.2014.09.029

[13] Liu, H., Chen, W., Liu, C., Liu, Y. and Dong, C. (2014) Magnetic Mesoporous Clay Adsorbent: 612 Preparation, Characterization and Adsorption Capacity for Atrazine. Microporous and Mesoporous Materials, 194, 72-78. https://doi.org/10.1016/j.micromeso.2014.03.038

[14] Bensacia, N., Fechete, I., Moulay, S., bbih-Boustila, S., Boos, A. and Garin, F. (2014) 
Removal of Cadmium (Ii) from Aqueous Media Using Cooh/Tud-1 Mesoporous Solid. Kinetic and Thermodynamic Studies. Environmental Engineering and Management Journal, 13, 2675-2686. https://doi.org/10.30638/eemj.2014.298

[15] Sarkar, A.K., Pal, A., Ghorai, S., Mandre, N.R. and Pal, S. (2014) Efficient Removal of Malachite Green Dye Using Biodegradable Graft Copolymer Derived from Amylopectin and Poly(acrylic acid). Carbohydrate Polymers, 111, 108-115. https://doi.org/10.1016/j.carbpol.2014.04.042

[16] Linley, S., Leshuk, T. and Gu, F.X. (2013) Magnetically Separable Water Treatment Technologies and Their Role in Future Advanced Water Treatment: A Patent Review. Clean-Soil, Air, Water, 41, 1152-1156.

https://doi.org/10.1002/clen.201100261

[17] Yan, L., Yang, K., Shan, R., Yan, T., Wei, J., Yu, S., Yu, H. and Du, B. (2015) Kinetic, Isotherm and Thermodynamic Investigations of Phosphate Adsorption onto Core-Shell $\mathrm{Fe}_{3} \mathrm{O}_{4} @ \mathrm{LDHs}$ Composites with Easy Magnetic Separation Assistance. Journal of Colloid and Interface Science, 448, 508-516. https://doi.org/10.1016/j.jcis.2015.02.048

[18] Tuhtan, A.D., Mandel, K., Paulus, A., Meyer, C. Hutter, F., Gellerman, C., Sexti, G., Franzreb, M. and Steinmetz, H. (2013) Phosphate Recovery from Wastewater Using Engineered Superparamagnetic Particles Modified with Layered Double Hydroxide Ion Exchangers. Water Research, 47, 5670-5677. https://doi.org/10.1016/j.watres.2013.06.039

[19] Oluseyi, A.K., Olarenwaju, A., Pal, M. and Das, K.S. (2016) Evaluation of Nigerian Source of Kaolin as a Raw Material for Mullite Synthesis. Oriental Journal of Chemistry, 32, 1571-1582. https://doi.org/10.13005/ojc/320333

[20] Adebowale, K.O., Unuabonah, I.I. and Olu-Owolabi, B.I. (2005) Adsorption of Some Heavy Metal Ions on Sulfate- and Phosphate-Modified Kaolin. Applied Clay Science, 29, 145-148. https://doi.org/10.1016/j.clay.2004.10.003

[21] Yan, L.G., Xu, Y.Y., Yu, H.Q., Xin, X.D. Wei, Q. and Pu, B. (2010) Adsorption of Phosphate from Aqueous Solution by Hydroxy-Aluminum, Hydroxy-Iron and Hydroxy-Iron-Aluminum Pillared Bentonites. Journal of Hazardous Materials, 179, 244-250. https://doi.org/10.1016/j.jhazmat.2010.02.086

[22] Lagergreen, S. (1898) Zur theorie der sogenannten adsorption gel`ster stoffe, Kungliga Svenska Vetenskapsakademiens. Handlingar, 24, 1-39.

[23] Cheung, C.W., Porter, J.F. and Mckay, G. (2001) Sorption Kinetic Analysis for the Removal of Cadmium Ions from Effluents Using Bone Char. Water Research, 35, 605-612. https://doi.org/10.1016/S0043-1354(00)00306-7

[24] Ho, Y.S. (2006) Review of Second-Order Models for Adsorption Systems. Journal of Hazardous Materials, 136, 681-689. https://doi.org/10.1016/j.jhazmat.2005.12.043

[25] Langmuir, I. (1912) Liquids. Journal of the American Chemical Society, 39, 1849-1906.

[26] Freundlich, H. (1906) Uber die adsorption in Losungen. Universitat Leipzig, Leipzig. https://doi.org/10.1515/zpch-1907-5723

[27] Saka, C., Sahin, O. and Celik, M.S. (2012b) Removal of Methylene Blue from Aqueous Solutions by Using Microwave Heating and Preboiling Treated Onion Skins as a New Adsorbent. Energy Sources, Part A, 34, 1577-1590. https://doi.org/10.1080/15567036.2010.525598

[28] Saka, C., Sahin, O., Adsoy, H. and Akyel, M.S. (2012) Removal of Methylene Blue from Aqueous Solutions by Using Cold Plasma, Microwave Radiation and Formaldehyde Treated Acorn Shells. Separation Science and Technology, 47, 1542-1551. 
https://doi.org/10.1080/01496395.2011.652284

[29] Mohtor, N.H., Othman, M.H.D., Ismail, A.F., Rahman, A.R., Jaafar, J. and Hashim, N.A. (2017) Investigation on the Effect of Sintering Temperature on Kaolin Hollow Fibre Membrane for Dye Filtration. Environmental Science and Pollution Research, 24, 15905-15917. https://doi.org/10.1007/s11356-017-9341-6

[30] Gao, L.B., Zhang, Q., Li, J.Y., Feng, R.T., Xu, H.Y. and Xue, C.Y. (2014) Adsorption of Methyl Orange on Magnetically Separable Mesoporous Titania Nanocomposite. Chinese Journal of Chemical Engineering, 22, 1168-1173. https://doi.org/10.1016/j.cjche.2014.09.015

[31] Pelosi, B.T., Lima, L.K.S. and Vieira, M.G.A. (2014) Removal of the Synthetic Dye Remazol Brilliant Blue R from Textile Industry Wastewaters by Biosorption on the Macrophyte Salvinia Natans. Brazilian Journal of Chemical Engineering, 31, 1035-1045. https://doi.org/10.1590/0104-6632.20140314s00002568

[32] Bakhtiary, S., Shirvani, M. and Shariatmadari, H. (2013) Characterization and 2,4-D Adsorption of Sepiolite Nanofibers Modified by N-Cetylpyridinium Cations. $\mathrm{Mi}$ croporous and Mesoporous Materials, 168, 30-36. https://doi.org/10.1016/j.micromeso.2012.09.022

[33] Unuabonah, E.I., Gunter, C., Weber, J., Lubahn, S. and Taubert, A. (2013) Hybrid Clay: A Newly Highly Efficient Adsorbent for Water Treatment. ACS Sustainable Chemistry \& Engineering, 1, 966-973. https://doi.org/10.1021/sc400051y

[34] Dikmen, S., Yilmaz, G., Yorukogullari, E. and Korkmaz, E. (2012) Zeta Potential Study of Natural Acids and Electrolyte Solutions. The Canadian Journal of Chemical Engineering, 90, 785-792. https://doi.org/10.1002/cjce.20573

[35] Igwe, J.C., Arukwe, U. and Anioke, S.N. (2013) Isotherm and Kinetic Studies of Residual Oil Adsorption from Palm Oil Mill Effluent (Pome) Using Boiler Fly Ash. Environmental Engineering and Management Journal, 12, 417-427. https://doi.org/10.30638/eemj.2013.052

[36] Li, H., Xu, W., Wang, N., Ma, X., Niu, D., Jiang, B., Liu, L., Huang, W., Yang, W. and Zhou, Z. (2012) Synthesis of Magnetic Molecularly Imprinted Polymer Particles for Selective Adsorption and Separation of Dibenzothiophene. Microchimica Acta, 179, 123-130. https://doi.org/10.1007/s00604-012-0873-7

[37] Zhang, G.S., Liu, H.J., Liu, R.P. and Qu, J.H. (2009) Removal of Phosphate from Water by a Fe-Mn Binary Oxide Adsorbent. Journal of Colloid and Interface Science, 335, 168-174. https://doi.org/10.1016/j.jcis.2009.03.019

[38] Uddin, M.K. (2017) A Review on the Adsorption of Heavy Metals by Clay Minerals with Special Focus on the Past Decades. Chemical Engineering Journal, 308, 418-462. https://doi.org/10.1016/j.cej.2016.09.029

[39] Ho, Y.S., Chiu, W.T., Hsu, C.S. and Huang, C.T. (2004) Sorption of Lead Ions from Aqueous Solution Using Tree Fern as a Sorbent. Hydrometallurgy, 73, 55-61. https://doi.org/10.1016/j.hydromet.2003.07.008

[40] Nagy, B., Szilagyi, B., Majdik, C., Katona, G., Indolean, C. and Maicaneanu, A. (2014) Cd (II) and Zn (II) Biosorption on Lactarius piperatus Macrofungus: Equilibrium Isotherm and Kinetic Studies. Environmental Progress \& Sustainable Energy, 33, 1158-1170. https://doi.org/10.1002/ep.11897

[41] Oliveira, L.C.A. and Rios, R.V.R.A. (2003) Clay-Iron Oxide Magnetic Composites for the Adsorption of Contaminants in Water. Applied Clay Science, 22, 169-177. https://doi.org/10.1016/S0169-1317(02)00156-4

[42] Shukla, A., Zheng, Y.H., ShulkaDubey, P., Margrare, J.L. and Shukla, S.S. (2002) 
The Role of Sawdust in the Removal of Unwanted Materials from Water. Journal of Hazardous Materials, 95, 137-152. https://doi.org/10.1016/S0304-3894(02)00089-4

[43] Yu, L.J., Shukla, S.S., Doris, K.L., Shukla, A. and Masgrave, J.L. (2003) Adsorption of CR from Aqueous Solution by Maple Sawdust. Journal of Hazardous Materials, 100, 53-63. https://doi.org/10.1016/S0304-3894(03)00008-6

[44] Zeng, H., Fisher, B. and Glammar, D.E. (2008) Individual and Competitive Adsorption of Arsenate and Phosphate to High Surface Area Iron Oxide Based Sorbent. Environmental Science \& Technology, 42, 147-152.

https://doi.org/10.1021/es071553d

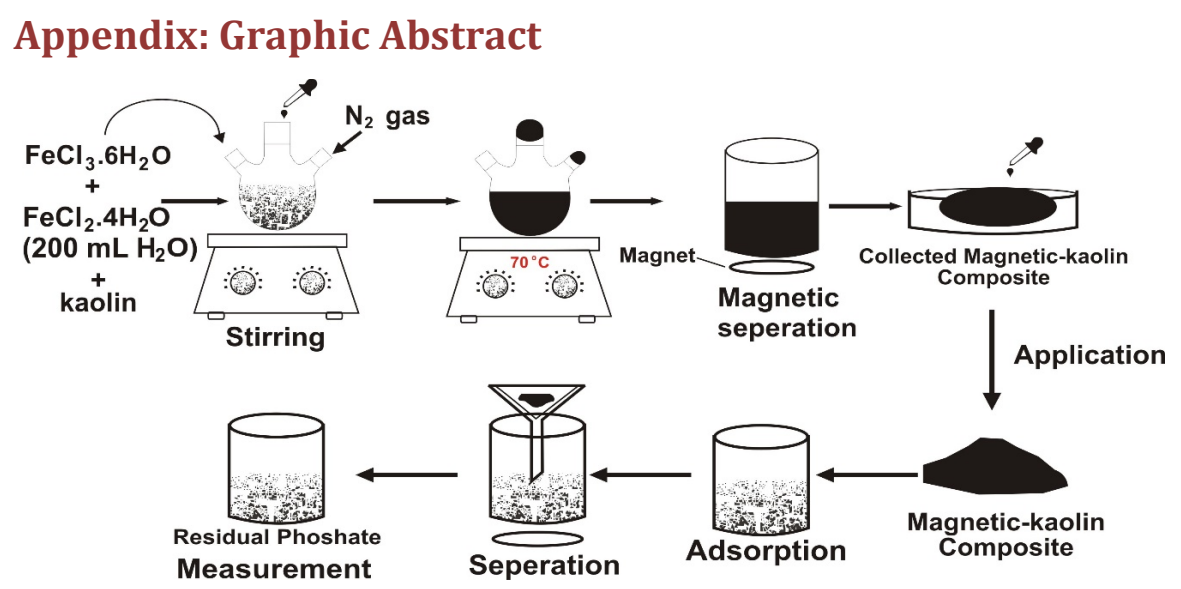

